\title{
Cerebral Arteriovenous Malformation Recurrence After Complete Surgical Excision in an Adult: Case Report and Review of the Literature
}

Daniel Loh ${ }^{1}$, Vincent $\mathrm{Ng}^{1}$

1. Neurosurgery, National Neuroscience Institute, Singapore, SGP

Corresponding author: Vincent Ng, vincent.ng.y.p@singhealth.com.sg

\begin{abstract}
Angiographically confirmed complete surgical excision of brain arteriovenous malformations (bAVMs) is conventionally considered curative. Recurrence in adults is rarely encountered; only 18 cases have been reported in the English literature over the past 30 years. The potential for recurrence and consequent need for routine long-term follow-up are important considerations in the management of these lesions. We report a case of a 23-year-old female with a recurrent bAVM discovered incidentally on routine imaging three years after complete surgical excision. We review the existing literature and discuss the options for surveillance and management.
\end{abstract}

Categories: Neurosurgery

Keywords: arteriovenous malformations, recurrence, adult, complete excision, follow-up

\section{Introduction}

Brain arteriovenous malformations (bAVMs) are congenital anomalies of dysplastic blood vessels with direct connections between arteries and veins without intervening capillaries which form a tangle of abnormal dilated channels called a nidus. Most of these lesions are discovered incidentally during imaging for other indications; symptomatic bAVMs most commonly present with haemorrhage and seizures [1-3]. bAVM recurrence after angiographically confirmed complete surgical resection is an uncommon but well recognized phenomenon in children, with an average rate of recurrence of $9.5 \%$ [4] (ranging from 2.8\% 16\%) [5-11], occurring from several months to 16 years after initial resection [12]. Recurrence is much rarer in adults, with only 18 cases reported in the English literature in the last 30 years. We report a case of bAVM recurrence in a patient who was 23 years old at the time of first presentation who had asymptomatic recurrence three years later.

Review began 05/17/2021 Review ended 05/25/2021 Published 06/01/2021

\section{(c) Copyright 2021}

Loh et al. This is an open access article distributed under the terms of the Creative Commons Attribution License CC-BY 4.0., which permits unrestricted use, distribution, and reproduction in any medium, provided the original author and source are credited.

\section{Case Presentation}

A 23-year-old right-handed lady with no medical history presented in April 2017 to a district general hospital with acute onset left brachiofacial hemiparesis. A computed tomography (CT) scan of the brain showed a right frontal intraparenchymal haematoma (Figure 1A) and CT angiogram (CTA) revealed a right frontal AVM (Figure $1 B$ ). She was transferred to our hospital for further management and a digital subtraction angiogram (DSA) was performed on the same day which showed a Spetzler-Martin grade $1 \mathrm{bAVM}$ with intranidal aneurysms in the right posterior frontal lobe measuring $2.4 \mathrm{~cm} \times 1.7 \mathrm{~cm} \times 0.8 \mathrm{~cm}$ supplied by branches of the right middle and anterior cerebral arteries draining into the superior sagittal sinus (Figure 1C). She was neurologically stable and planned for delayed surgical resection to await partial clot liquefaction. However, she deteriorated three days later with a drop in her Glasgow Coma Scale (GCS) score from 15 to E3V2M4. An urgent CTA showed marked increase in size of the haematoma with extensive intraventricular extension and a $6 \mathrm{~mm}$ CT-spot sign suggesting active haemorrhage (Figure 1D). 


\section{Cureus}

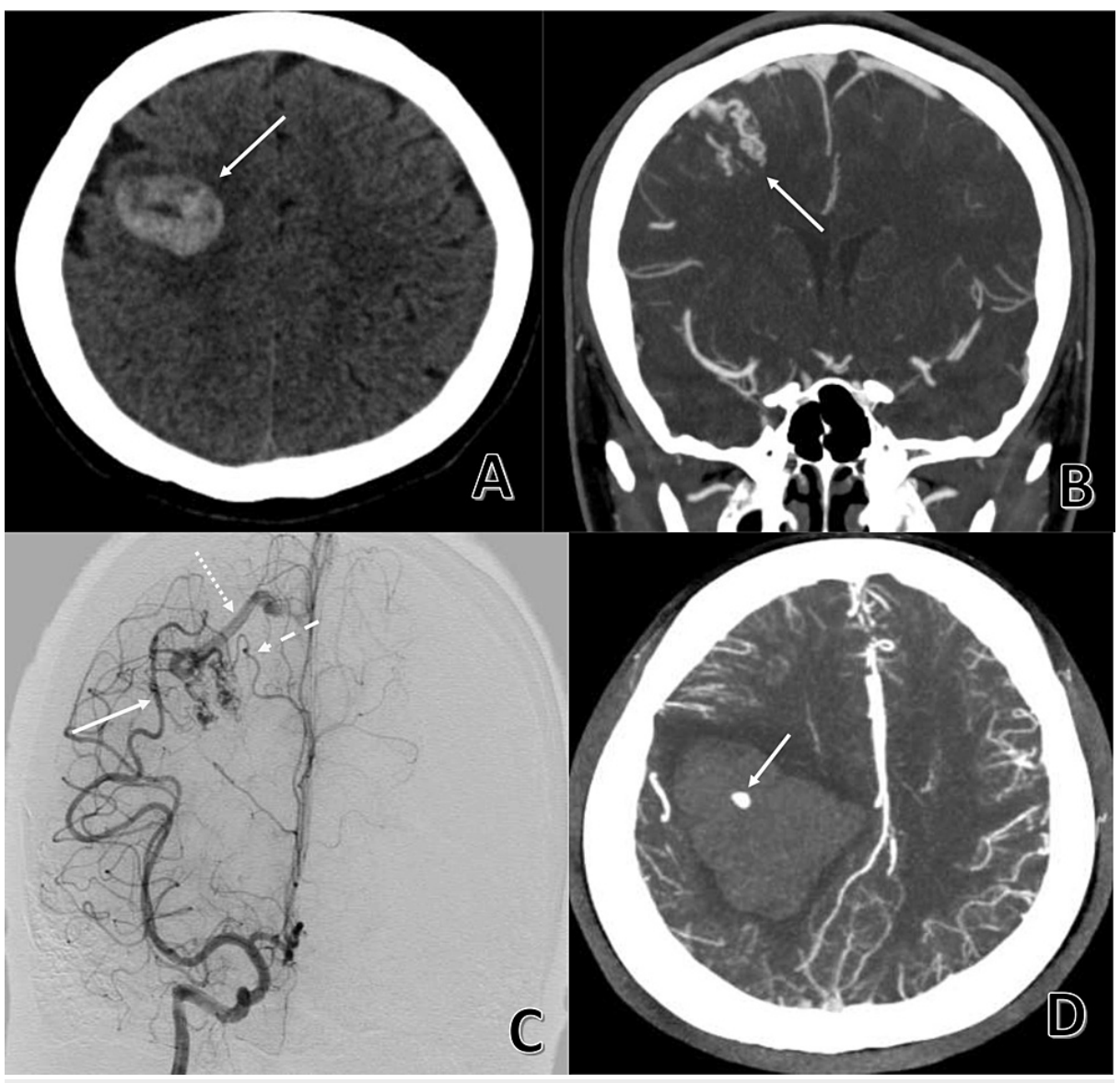

FIGURE 1: Computed tomography (A, B and D) and catheter angiogram (C) demonstrating the Spetzler-Martin grade 1 brain arteriovenous malformation and the associated intraparenchymal haematoma

(A) Computed tomography showing a right frontal haematoma (solid arrow). (B) Computed tomography angiogram revealing a right frontal brain arteriovenous malformation (solid arrow). (C) Digital subtraction angiogram demonstrating the brain arteriovenous malformation fed by branches of the middle cerebral artery (solid arrow) and anterior cerebral artery (dashed arrow) with superficial drainage into the superior sagittal sinus (dotted arrow). (D) Urgent computed tomography after clinical deterioration showing haematoma expansion, intra-ventricular extension and evidence of contrast extravasation suggestive of active bleeding (solid arrow).

She was taken to theatre emergently for decompressive craniectomy, evacuation of the haematoma and excision of the bAVM. Intra-operative indocyanine green (ICG) angiography revealed two main arterial feeders on the cortical surface and one main draining vein to the superior sagittal sinus. The bAVM was excised en-bloc and post-excision ICG showed no remnant which was confirmed on immediate postoperative DSA (Figure 2). 


\section{Cureus}

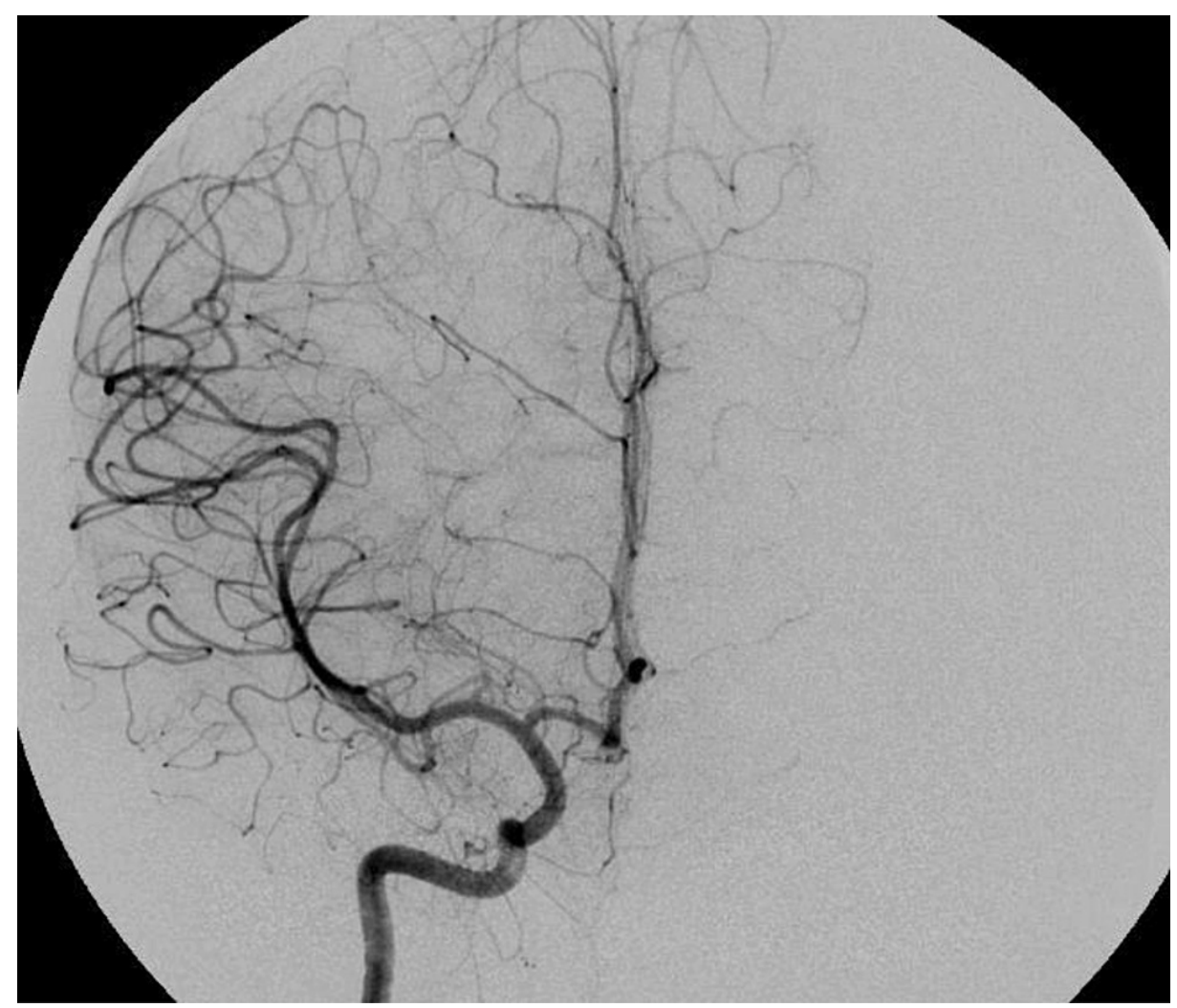

FIGURE 2: Immediate post-operative digital subtraction angiogram showing no residual brain arteriovenous malformation

She was transferred to our rehabilitation centre 19 days after surgery. While undergoing rehabilitation she had a generalised seizure attributed to scar epilepsy which was controlled with levetiracetam. She recovered well; her Functional Independence Measure (FIM) score improved from 28 to 108, and she had a cranioplasty implant four months later. She remained clinically well on six-monthly follow-up apart from another seizure in June 2018. A non-enhanced CT showed no haemorrhage and she had no further seizures after the dose of levetiracetam was increased. A routine CTA in August 2020 showed partial recanalization of the same bAVM nidus, now supplied via tiny right middle cerebral artery (MCA) (and possibly anterior cerebral artery [ACA]) cortical branch(es) with venous drainage towards the superior sagittal sinus (Figure 3). 


\section{Cureus}

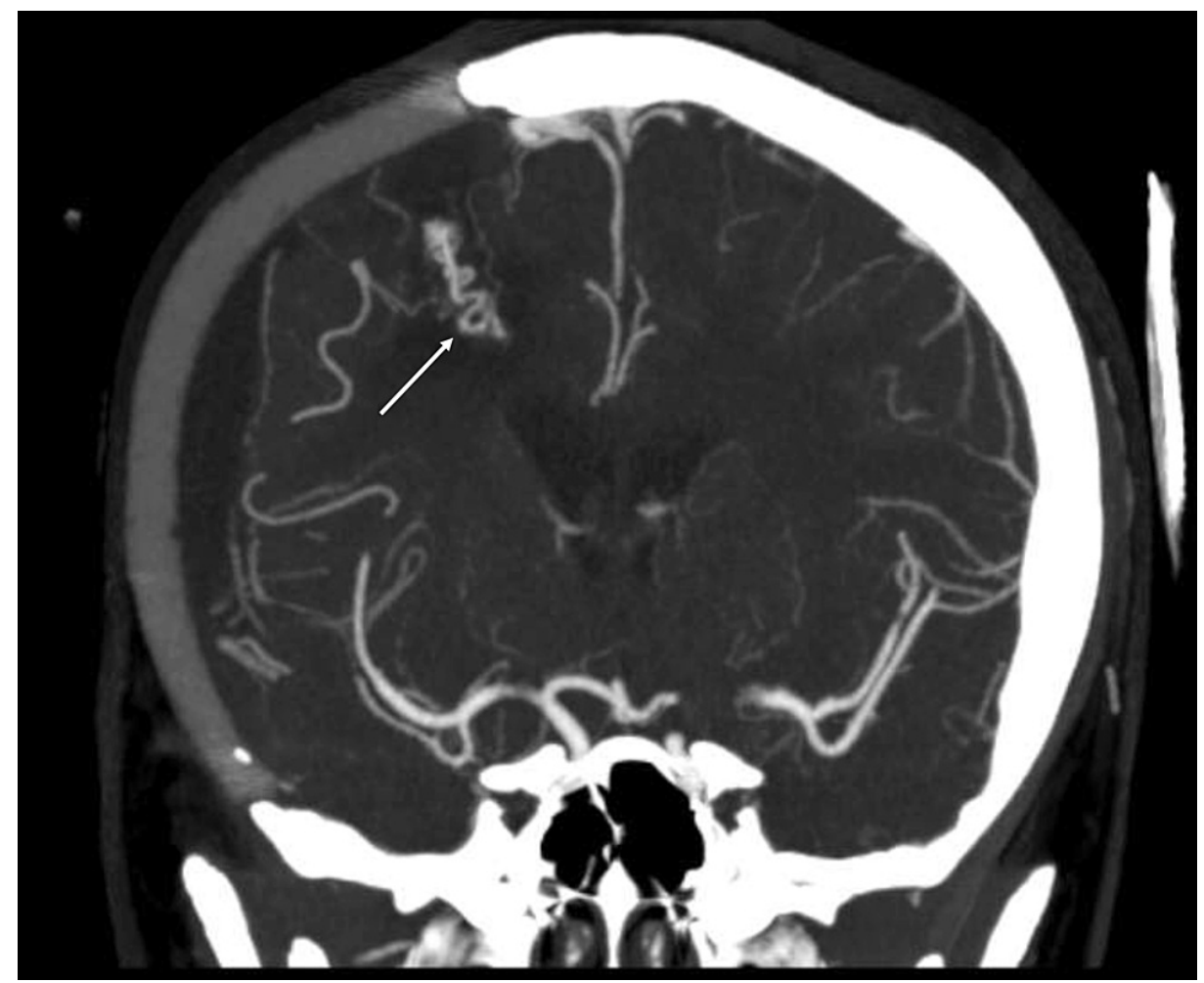

FIGURE 3: Routine computed tomography angiogram revealing recurrence of the brain arteriovenous malformation (solid arrow) in the same location as the one excised three years ago

In light of her age and good functional status, repeat surgical resection was recommended although the option of stereotactic radiosurgery was also offered. After consulting with a radiosurgeon, she decided to proceed with surgical resection. A stereotactic CTA repeated in February 2021 showed stable size of the bAVM. She underwent resection of the recurrent AVM in March 2021 with stereotactic navigation via CTA. Intra-operatively, small cortical feeders were seen which were taken circumferentially; no large draining vein was identified. Post-operative day 1 CTA showed no remnant bAVM (Figure 4). She had an uneventful post-operative course; her function remained at baseline and she was discharged well one week after surgery with a plan for delayed DSA after a few months. 


\section{Cureus}

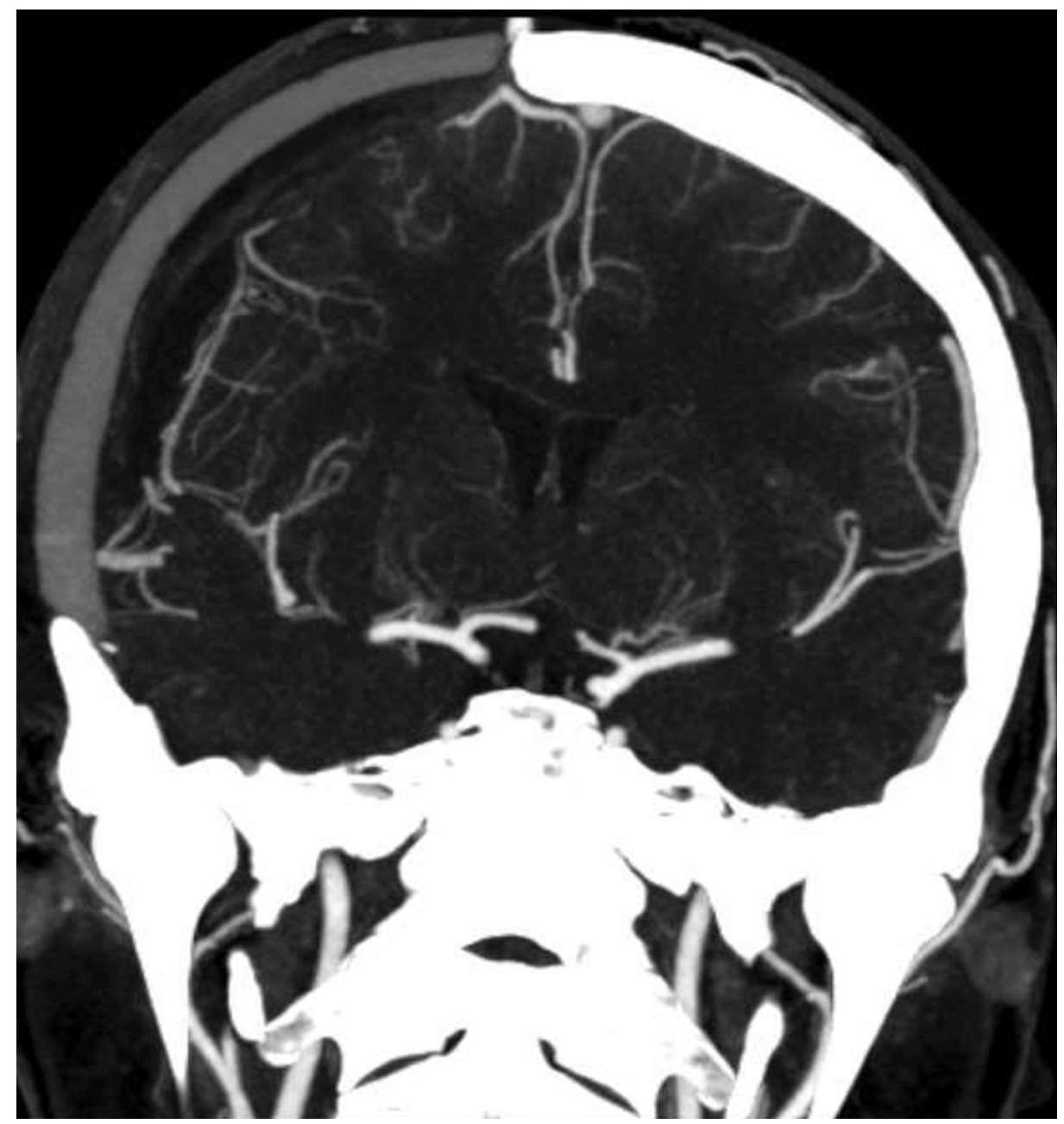

FIGURE 4: Post-operative day 1 computed tomography angiogram showing no residual brain arteriovenous malformation

\section{Discussion}

bAVM recurrence in adults after angiographically demonstrated complete excision is a rare phenomenon. Only sporadic case reports/series exist; just 18 cases have been reported in the English literature over the last 30 years (Table 1) [9, 13-15, 16-24]. Age at initial presentation ranged from 19 to 51, recurrence was observed from several months to 16 years after resection with all except one discovered within 10 years. No predilection for gender or bAVM location is apparent. Patients in earlier reports presented symptomatically with haemorrhage or seizures while those reported more recently were discovered on routine imaging during follow-up. Most cases (10/18) were managed by surgical resection. In our case, the isolated seizure in June 2018 may have represented clinical manifestation of her bAVM recurrence which was discovered on routine follow-up imaging three years later and treated by repeat surgical excision. 


\begin{tabular}{|c|c|c|c|c|c|c|c|}
\hline Authors, year & $\begin{array}{l}\text { Number } \\
\text { of cases }\end{array}$ & $\begin{array}{l}\text { Age at first } \\
\text { presentation }\end{array}$ & Gender & $\begin{array}{l}\text { Duration till } \\
\text { recurrence } \\
\text { (years) }\end{array}$ & Location of AVM & Discovery & Management \\
\hline $\begin{array}{l}\text { Fuwa et al., } 1988 \\
\text { [16] }\end{array}$ & 1 & 23 & $\mathrm{~F}$ & 5 & Right temporal & Routine imaging & $\begin{array}{l}\text { Surgical } \\
\text { resection }\end{array}$ \\
\hline $\begin{array}{l}\text { Gabriel et al., } \\
1996 \text { [17] }\end{array}$ & 1 & 19 & M & 9 & Left frontotemporal & Seizure & $\begin{array}{l}\text { Surgical } \\
\text { resection }\end{array}$ \\
\hline $\begin{array}{l}\text { Pellettieri et al., } \\
1997 \text { [15] }\end{array}$ & 1 & 29 & $\mathrm{~F}$ & 15 & Right frontal & Seizure & $\begin{array}{l}\text { Not } \\
\text { mentioned }\end{array}$ \\
\hline $\begin{array}{l}\text { Hashimoto \& } \\
\text { Nozaki, } 1999 \text { [18] }\end{array}$ & 2 & 24,23 & $\mathrm{M}, \mathrm{F}$ & 8,6 & $\begin{array}{l}\text { Left basal ganglia, Right } \\
\text { frontal }\end{array}$ & Haemorrhage & $\begin{array}{l}\text { Not } \\
\text { mentioned }\end{array}$ \\
\hline $\begin{array}{l}\text { Hino et al., } 1999 \\
\text { [19] }\end{array}$ & 1 & 28 & M & 4 & Right frontal & Haemorrhage & SRS \\
\hline $\begin{array}{l}\text { Santoro et al., } \\
2000[20]\end{array}$ & 1 & 24 & $\mathrm{M}$ & 6 & Right temporal & Seizure & $\begin{array}{l}\text { Surgical } \\
\text { resection }\end{array}$ \\
\hline $\begin{array}{l}\text { Codd et al., } 2008 \\
\text { [14] }\end{array}$ & 1 & 26 & $\mathrm{~F}$ & 7 & Left occipital & Haemorrhage & $\begin{array}{l}\text { Surgical } \\
\text { resection }\end{array}$ \\
\hline $\begin{array}{l}\text { Musluman et al., } \\
2011 \text { [21] }\end{array}$ & 1 & 35 & $\mathrm{~F}$ & 5 & Left occipital & Seizure & $\begin{array}{l}\text { Surgical } \\
\text { resection }\end{array}$ \\
\hline $\begin{array}{l}\text { Wostrack et al., } \\
2011 \text { [22] }\end{array}$ & 1 & 30 & $\mathrm{~F}$ & 2.5 & Left parietal & Routine imaging & $\begin{array}{l}\text { Surgical } \\
\text { resection }\end{array}$ \\
\hline $\begin{array}{l}\text { Morgan et al., } \\
2012 \text { [9] }\end{array}$ & 3 & $42,26,28$ & $F, M, F$ & $3,1.5,2.5$ & $\begin{array}{l}\text { Left temporal, } \\
\text { Midbrain/thalamus, } \\
\text { Cingulate }\end{array}$ & $\begin{array}{l}\text { Routine imaging all } \\
3\end{array}$ & $\begin{array}{l}\text { Surgical } \\
\text { resection all } \\
3\end{array}$ \\
\hline $\begin{array}{l}\text { Weingarten et al., } \\
2012 \text { [23] }\end{array}$ & 1 & $20 \mathrm{~s}$ & M & 0.5 & Left frontoparietal & Routine imaging & $\begin{array}{l}\text { Embolisation } \\
+ \text { SRS }\end{array}$ \\
\hline $\begin{array}{l}\text { Ivanov et al., } 2016 \\
\text { [13] }\end{array}$ & 3 & $36,30,31$ & $F, F, M$ & $3,1,3$ & $\begin{array}{l}\text { Left splenium, Right } \\
\text { splenium, Left frontal }\end{array}$ & $\begin{array}{l}\text { Routine imaging } \\
\text { first } 2 \text { Headache }\end{array}$ & SRS all 3 \\
\hline $\begin{array}{l}\text { Marutani et al., } \\
2020[24]\end{array}$ & 1 & 51 & $\mathrm{~F}$ & 5 & Right temporal & Haemorrhage & $\begin{array}{l}\text { Surgical } \\
\text { resection }\end{array}$ \\
\hline
\end{tabular}

TABLE 1: Summary of reported cases of AVM recurrence after complete excision in adult patients

AVM: Arteriovenous malformation; SRS: Stereotactic radiosurgery.

Identified risk factors for bAVM recurrence include initial presentation with haemorrhage [8], the presence of deep venous drainage [9], a diffuse nidus [11] and treatment with preoperative embolization [13].

These factors are largely consistent with the postulated mechanisms behind bAVM recurrence. The first is that recurrence actually represents residual nidus that was angiographically occult due to obscuration from vessel spasm, temporary thrombosis or mass effect from adjacent haematoma or cerebral oedema during the immediate post-operative period. Subsequent resolution would then result in recanalisation of the remnant shunt $[10,14]$. Another possibility is the concept of "hidden compartments" which are unfilled regions of the AVM contiguous with or adjacent to the active nidus because of low or absent flow from internal steal that develop from the change in haemodynamics following resection [15].

Recurrence can also be a result of neoangiogenesis and de novo bAVM formation, which would readily explain the far greater incidence of bAVM recurrence in the paediatric population. Elevated levels of vascular endothelial growth factor (VEGF) have been found in adult samples [25], and higher rates of elevated VEGF expression have been demonstrated in paediatric cases with bAVM recurrence compared to paediatric and adult cases without recurrence [26]. Increased expression of other angiogenetic factors such as KRAS mutations [27], phosphorylated extracellular signal-regulated kinase (pERK) and CD105 (endoglin) [28] has also been reported. De novo bAVM formation after venous sinus thrombosis has also been observed, with impaired venous outflow leading to congestion, parenchymal ischaemia and hypoxia and increased 
angiogenesis as the proposed mechanism [29].

There is little evidence to guide the duration, schedule and modality of follow-up imaging in adult patients after complete surgical resection; there is no consensus even in the paediatric literature [30,31]. Based on suggested follow-up in children [31] and from the adult cases thus far, follow-up for 10 years, with routine imaging at 1 year, 5 years, 10 years and for any new or progressive neurological signs and symptoms, would be reasonable. Although DSA is still the gold standard modality and was utilized to detect recurrence in all reported cases, a 2019 study found that contrast-enhanced magnetic resonance imaging and angiography (MRI/MRA) was suitable for surveillance, with DSA subsequently used for confirmation [32].

The appropriate treatment strategy is similarly poorly established, and the risk of re-rupture of these recurrent bAVMs is unknown. Just over half the adult recurrences were treated by surgical excision, stereotactic radiosurgery (SRS) was the next most common option. A systematic review in 2018 that included paediatric cases found that surgery (59\%) and SRS (37\%) were the most common methods of treatment [4] and a recent consensus paper recommended that recurrent lesions be treated surgically [33]. Ultimately, decisions on treatment of these lesions should be reached via consensus between the patient and clinician after a comprehensive discussion of the risks and benefits. In this case, the existing cranioplasty posed an additional element of complexity to the consideration for repeat surgery.

\section{Conclusions}

bAVM recurrence in adults after complete surgical resection is a rare but potentially important phenomenon. Routine follow-up imaging over an extended duration may be warranted, especially in cases with one or more risk factors for recurrence. New or progressive clinical manifestations should similarly trigger vascular imaging. Non-invasive imaging modalities may be a viable alternative to DSA for surveillance. Repeat surgical excision and SRS were the most common methods of treatment.

\section{Additional Information \\ Disclosures}

Human subjects: Consent was obtained or waived by all participants in this study. Conflicts of interest: In compliance with the ICMJE uniform disclosure form, all authors declare the following: Payment/services info: All authors have declared that no financial support was received from any organization for the submitted work. Financial relationships: All authors have declared that they have no financial relationships at present or within the previous three years with any organizations that might have an interest in the submitted work. Other relationships: All authors have declared that there are no other relationships or activities that could appear to have influenced the submitted work.

\section{References}

1. Lawton MT, Rutledge WC, Kim H, et al.: Brain arteriovenous malformations. Nat Rev Dis Primers. 2015, 1:15008. 10.1038/nrdp.2015.8

2. Solomon RA, Connolly ES Jr: Arteriovenous malformations of the brain . N Engl J Med. 2017, 376:1859-1866. 10.1056/NEJMra1607407

3. Derdeyn CP, Zipfel GJ, Albuquerque FC, Cooke DL, Feldmann E, Sheehan JP, Torner JC: Management of brain arteriovenous malformations: a scientific statement for healthcare professionals from the American Heart Association/American Stroke Association. Stroke. 2017, 48:200-224. 10.1161/STR.0000000000000134

4. Sorenson TJ, Brinjikji W, Bortolotti C, Kaufmann G, Lanzino G: Recurrent brain arteriovenous malformations (AVMs): a systematic review. World Neurosurg. 2018, 116:856-866. 10.1016/j.wneu.2018.05.117

5. Kader A, Goodrich JT, Sonstein WJ, Stein BM, Carmel PW, Michelsen WJ: Recurrent cerebral arteriovenous malformations after negative postoperative angiograms. J Neurosurg. 1996, 85:14-18. 10.3171/jns.1996.85.1.0014

6. Kondziolka D, Humphreys RP, Hoffman HJ, Hendrick EB, Drake JM: Arteriovenous malformations of the brain in children: a forty year experience. Can J Neurol Sci. 1992, 19:40-45.

7. Klimo P Jr, Rao G, Brockmeyer D: Pediatric arteriovenous malformations: a 15-year experience with an emphasis on residual and recurrent lesions. Childs Nerv Syst. 2007, 23:31-37. 10.1007/s00381-006-0245-X

8. Copelan A, Drocton G, Caton MT, et al.: Brain arteriovenous malformation recurrence after apparent microsurgical cure: increased risk in children who present with arteriovenous malformation rupture. Stroke. 2020, 51:2990-2996. 10.1161/STROKEAHA.120.030135

9. Morgan MK, Patel NJ, Simons M, Ritson EA, Heller GZ: Influence of the combination of patient age and deep venous drainage on brain arteriovenous malformation recurrence after surgery. J Neurosurg. 2012, 117:934-941. 10.3171/2012.8.JNS12351

10. Aboukaïs R, Vinchon M, Quidet M, Bourgeois P, Leclerc X, Lejeune JP: Reappearance of arteriovenous malformations after complete resection of ruptured arteriovenous malformations: true recurrence or falsenegative early postoperative imaging result?. J Neurosurg. 2017, 126:1088-1093. 10.3171/2016.3.JNS152846

11. Lang SS, Beslow LA, Bailey RL, Vossough A, Ekstrom J, Heuer GG, Storm PB: Follow-up imaging to detect recurrence of surgically treated pediatric arteriovenous malformations. J Neurosurg Pediatr. 2012, 9:497504. 10.3171/2012.1.PEDS11453

12. Weil AG, Li S, Zhao JZ: Recurrence of a cerebral arteriovenous malformation following complete surgical resection: a case report and review of the literature. Surg Neurol Int. 2011, 2:175. 10.4103/2152-7806.90692 
13. Ivanov AA, Alaraj A, Charbel FT, Aletich V, Amin-Hanjani S: Recurrence of cerebral arteriovenous malformations following resection in adults: does preoperative embolization increase the risk?. Neurosurgery. 2016, 78:562-571. 10.1227/NEU.0000000000001191

14. Codd PJ, Mitha AP, Ogilvy CS: A recurrent cerebral arteriovenous malformation in an adult . J Neurosurg. 2008, 109:486-491. 10.3171/JNS/2008/109/9/0486

15. Pellettieri L, Svendsen P, Wikholm G, Carlsson CA: Hidden compartments in AVMs--a new concept . Acta Radiol. 1997, 38:2-7. 10.1080/02841859709171233

16. Fuwa I, Wada H, Matsumoto T: Recurrence of AVM after disappearing on postoperative angiography--report of two cases (Article in Japanese). No Shinkei Geka. 1988, 16:887-891.

17. Gabriel EM, Sampson JH, Wilkins RH: Recurrence of a cerebral arteriovenous malformation after surgical excision. Case report. J Neurosurg. 1996, 84:879-882. 10.3171/jns.1996.84.5.0879

18. Hashimoto N, Nozaki K: Do cerebral arteriovenous malformations recur after angiographically confirmed total extirpation?. Crit Rev Neurosurg. 1999, 9:141-146. 10.1007/s003290050123

19. Hino A, Fujimoto M, Iwamoto Y, Takahashi Y, Katsumori T: An adult case of recurrent arteriovenous malformation after "complete" surgical excision: a case report. Surg Neurol. 1999, 52:156-159. 10.1016/s0090-3019(99)00060-9

20. Santoro A, Giuliani S, Paolini S: Recurrent arteriovenous malformation in an adult. Case illustration . I Neurosurg. 2000, 93:1082. 10.3171/jns.2000.93.6.1082

21. Musluman AM, Cavusoglu H, Yilmaz A, Aydin Y: Recurrent cerebral arteriovenous malformation with a posterior inferior cerebellar artery aneurysm. Turk Neurosurg. 2011, 21:674-679.

22. Wostrack M, Meyer B, Stoffel M: Asymptomatic arteriovenous malformation recurrence in an adult. Acta Neurochir (Wien). 2011, 153:1821-1823. 10.1007/s00701-011-1083-5

23. Weingarten D, Pakbaz S, Cho A, U HS: An early venous abnormality: a potential cause of arteriovenous malformation recurrence. BMJ Case Rep. 2012, 2012:bcr0120125646. 10.1136/bcr.01.2012.5646

24. Marutani A, Nakano R, Yamada T: Recurrence of arteriovenous malformation in adulthood five years after complete surgical resection: a case report. Neurochirurgie. 2020, 66:405-407. 10.1016/j.neuchi.2020.06.124

25. Koizumi T, Shiraishi T, Hagihara N, Tabuchi K, Hayashi T, Kawano T: Expression of vascular endothelial growth factors and their receptors in and around intracranial arteriovenous malformations. Neurosurgery. 2002, 50:117-126. 10.1097/00006123-200201000-00020

26. Sonstein WJ, Kader A, Michelsen WJ, Llena JF, Hirano A, Casper D: Expression of vascular endothelial growth factor in pediatric and adult cerebral arteriovenous malformations: an immunocytochemical study. J Neurosurg. 1996, 85:838-845. 10.3171/jns.1996.85.5.0838

27. Nikolaev SI, Vetiska S, Bonilla X, et al.: Somatic activating KRAS mutations in arteriovenous malformations of the brain. N Engl J Med. 2018, 378:250-261. 10.1056/NEJMoa1709449

28. Takagi Y, Kikuta K, Nozaki K, Hashimoto N: Early regrowth of juvenile cerebral arteriovenous malformations: report of 3 cases and immunohistochemical analysis. World Neurosurg. 2010, 73:100-107. 10.1016/j.surneu.2009.07.008

29. Shi S, Gupta R, Moore JM, et al.: De novo AVM formation following venous sinus thrombosis and prior AVM resection in adults: report of 2 cases. J Neurosurg. 2018, 128:506-510. 10.3171/2016.9.JNS161710

30. Jimenez JE, Gersey ZC, Wagner J, Snelling B, Ambekar S, Peterson EC: Role of follow-up imaging after resection of brain arteriovenous malformations in pediatric patients: a systematic review of the literature. J Neurosurg Pediatr. 2017, 19:149-156. 10.3171/2016.9.PEDS16235

31. Morgenstern PF, Hoffman CE, Kocharian G, Singh R, Stieg PE, Souweidane MM: Postoperative imaging for detection of recurrent arteriovenous malformations in children. J Neurosurg Pediatr. 2016, 17:134-140. 10.3171/2015.6.PEDS14708

32. Jhaveri A, Amirabadi A, Dirks P, et al.: Predictive value of MRI in diagnosing brain AVM recurrence after angiographically documented exclusion in children. AJNR Am J Neuroradiol. 2019, 40:1227-1235. 10.3174/ajnr.A6093

33. Kato Y, Dong VH, Chaddad F, et al.: Expert consensus on the management of brain arteriovenous malformations. Asian J Neurosurg. 2019, 14:1074-1081. 10.4103/ajns.AJNS_234_19 